\title{
Peningkatan Aktivitas dan Hasil Belajar Siswa dalam Pembelajaran Kimia Menggunakan Model Pembelajaran Discovery Learning di SMA Negeri 1 Praya Barat
}

\author{
Sahnam \\ SMA Negeri 1 Praya Barat, Kabupaten Lombok Tengah - Provinsi NTB \\ *Corresponding Author. Email: sahnam69@gmail.com
}

\begin{abstract}
This study aims to increase the activeness and learning outcomes of students' chemistry by applying the Discovery Learning learning model to electrolyte and non-electrolyte solutions at SMA Negeri 1 Praya Barat. This research is a classroom action research conducted in two cycles. The research subjects were all students of class X-MIPA-1, totaling 31 students. In this study, student learning activities were obtained through observation while learning outcomes were obtained through formative tests. The results of this study indicate; 1) Students' chemistry learning activities increase by applying the Discovery Learning learning model to the electrolyte and non-electrolyte solution material according to the two observations in Cycle I of writing and reading activities $50 \%$, doing worksheets $20 \%$, asking friends $10 \%$, asking teachers $5 \%$, and those that are not relevant to teaching and learning activities are 5\%, while according to the observations of Cycle II, writing and reading activities are $21 \%$, doing LKS 50\%, asking friends $13 \%$, asking teachers $16 \%$, and those not relevant to teaching and learning activities are 1\%;2) Students' chemistry learning outcomes increased in the Formative I test showing 18 students completed individually, while in Cycle II 28 students completed individually and the class completed with an average of cycle I and cycle II were 69 and 88 and the percentage of classical completeness was $58 \%$ in the first cycle and $90 \%$ in the second cycle.
\end{abstract}

Abstrak: Penelitian ini bertujuan untuk meningkatkan keaktifan dan hasil belajar kimia siswa dengan menerapkan model pembelajaran Discovery Learning pada materi larutan elektrolit dan non elektrolit di SMA Negeri 1 Praya Barat. Penelitian ini adalah penelitian tindakan kelas yang dilakukan dalam dua siklus. Subjek penelitian adalah seluruh siswa kelas X-MIPA-1 yang berjumlah 31 siswa. Dalam penelitian ini, aktivitas belajar siswa diperoleh melalui observasi sedangkan hasil belajar melalui tes formatif. Hasil penelitian ini menunjukkan; 1) Aktivitas belajar kimia siswa meningkat menurut kedua pengamatan pada Siklus I aktivitas menulis dan membaca 50\%, mengerjakan LKS $20 \%$, bertanya sesamateman $10 \%$, bertanya kepada guru $5 \%$, dan yang tidak relevan dengan kegiatan belajar mengajar 5\%, sedangkan menurut pengamatan Siklus II aktivitas menulis dan membaca $21 \%$, mengerjakan LKS $50 \%$, bertanya sesama teman $13 \%$, bertanya kepada guru16\%, dan yang tidak relevan dengan kegiatan belajar mengajar 1\%; 2) Hasil belajar kimia siswa meningkatpada tes Formatif I menunjukkan 18 orang siswa tuntas secara individu, sedangkan pada Siklus II 28 orang siswa tuntas secara individu dan kelas tuntas dengan rata-rata siklus I dan siklus II adalah 69 dan 88 dan persentase ketuntasan klasikal adalah $58 \%$ pada siklus I dan $90 \%$ pada siklus II.

\section{Article History}

Received: 29-08-2020

Reviewed: 12-09-2021

Accepted: 25-09-2021

Published: 18-10-2021

\section{Key Words}

Learning Activities, Learning Outcomes, Discovery Learning

\section{Sejarah Artikel}

Diterima: 29-08-2020

Direview: 12-09-2021

Disetujui: 25-09-2021

Diterbitkan: 18-10-2021

\section{Kata Kunci}

Aktivitas Belajar, Hasil

Belajar Discovery

Learning

How to Cite: Sahnam, S. (2021). Peningkatan Aktivitas dan Hasil Belajar Siswa dalam Pembelajaran Kimia Menggunakan Model Pembelajaran Discovery Learning di SMA Negeri 1 Praya Barat. Jurnal Teknologi Pendidikan : Jurnal Penelitian dan Pengembangan Pembelajaran, 6(2), 168-177. doi:https://doi.org/10.33394/jtp.v6i2.4212 


\section{Pendahuluan}

Proses belajar mengajarmerupakan adalah suatu proses interaksi atau hubungan timbal balik antara guru dan siswa dalam satuan pembelajaran.Keberhasilan pembelajaran ditentukan oleh besarnya partisipasi guru dan siswa dalam mengikuti pembelajaran. Semakin siswa berperan aktif maka semakin besar peluang keberhasilan kegiatan pembelajaran tersebut (Luthfi, et al, 2021; Suarni et al, 2021). Keterampilan guru juga sangat penting dalam menyampaikan materi saat proses belajar mengajar yang dapat mencapai tujuan pembelajaran, sehingga hasil belajar siswa meningkat. Guru diharapkan dapat inovatif dan kreatif untuk mengikuti perkembangan pendidikan saat ini. Guru harus mampu membuat pembelajaran menjadi menyenangkan, menjelaskan materi-materi dengan baik, siswa menjadi pribadi yang baik, serta menggunakan media pembelajaran yang interaktif hal ini dapat mempermudah siswa dalam proses kegiatan pembelajaran (Anisa et al, 2021; Nurmiati, 2020; Saufi \& Rizka, 2021)

Dari pengalaman selama mengajar di SMA Negeri 1 Praya Barat, keterlibatan aktif siswa dalam pembelajaran masih rendah. Faktor ini dapat menghambat keberhasilan dari tujuan pembelajaran kimia, yaitu siswa tidak dapat memahami materi pelajaran dan dapat mengaitkannya dalam kehidupan nyata. Berbagai upaya terus dilakukanpeneliti sebagai guru dalam memperbaiki situasi pembelajaran di dalam kelas. Berbagai model, metode dan strategi pembelajaran dilakukan guna mengikuti perkembangan progresif yang dicanangkan dalam memperbaiki kualitas pembelajaran kimia. Jalan keluar yang dapat dilakukan untuk meningkatkan hasil belajar siswa dalam mata pelajaran kimia adalah melakukan eksperimen, dan diskusi sehingga siswa mudah memahami materi yang diajarkan. Model pembelajaran yang digunakan dalam penelitian ini adalah model pembelajaran berbasis saintifik dengan model pembelajaran Discovery Learning.

Model pembelajaran Discovery Learning merupakan salah satu solusi yang dapat digunakan untuk meningkatkan kemampuan kognitif siswa dalam proses pembelajaran (Fitriana, 2019; Mahartati, 2017; Trianto, 2007). Model pembelajaran Discovery Learning dilakukan untuk membangkitkan minat siswa (engagement), memanfaatkan kegiatan telaah literatur (exploration), memberikan kesempatan siswa untuk menyampaikan ide dalam diskusi(explaination), mengajak siswamengaplikasikan konsep dengan mengerjakan soalsoal (elaboration) dan terdapat suatu tes akhir untuk mengetahui tingkat pemahaman siswa terhadap konsep yang telah dipelajari (evaluation) (Deviana, et al., 2021; Raihun, 2019; Setiarini, 2016).

Adapun tujuan penelitian ini adalah untuk mengetahui peningkatan aktivitas belajar kimia siswa dan peningkatan hasil belajar kimia siswa selama mengikuti pembelajaran dengan menggunakan model pembelajaran Discovery Learning pada materi larutan elektrolit dan non elektrolit di kelas X-MIPA-1 SMA Negeri 1 Praya Barat tahun pelajaran 2019/2020.

\section{Metode Penelitian}

Penelitian ini menggunakan Penelitian Tindakan Kelas (PTK) yang menggunakan model penelitian tindakan dari Kemmis dan Taggar (dalam Aqib, 2006) yang berbentuk spiral dari siklus yang satu ke siklus yang berikutnya. Setiap siklus meliputi planning (rencana), action (tindakan), observation (pengamatan), dan reflection (refleksi). Sebelum masuk pada Siklus I dilakukan tindakan pendahuluan yang berupa identifikasipermasalahan. Penelitian dilakukan di SMA Negeri 1 Praya Barat kelas X-MIPA-1 tahun pelajaran 2019/2020. Subjek penelitian adalah siswa kelas X-MIPA-1 SMA Negeri 1 Praya Barat 
yang berjumlah 31 siswa. Instrumen Penelitian ini menggunakan tes dan lembar observasi.

Analisa data pada penelitian ini menggunakan teknik analisis deskriptif kualitatif, untuk mengalisis tingkat keberhasilan atau persentase keberhasilan siswa setelah proses belajar mengajar setiap putarannya dilakukan dengan cara memberikan evaluasi berupa soal tes tertulis pada setiap akhir siklus. Analisis aktivitas dan hasil formatif dihitung dengan menggunakan statistik. Ada dua kategori ketuntasan belajar yaitu secara persiswaan dan secara klasikal. Untuk ketuntasan individu siswa maka digunakan KKM sekolah. KKM mata pelajaran kimia kelas X-MIPA-1 adalah 75. Dalam penelitian ini, kelas disebut tuntas belajar bila di kelas tersebut terdapat paling tidak $85 \%$ siswa yang telah mencapai daya serap $\geq$ KKM. Untuk menganalisis data hasil observasi aktivitas siswa digunakan rumus sebagai berikut:

$$
\%=\frac{\bar{X}}{\sum X} \times 100 \% \text { dengan }
$$

Indikator keberhasilan dalam penelitian ini adalahdengan menggunakan KKM mata pelajaran kimia. Penelitian dikatakan berhasil apabila $85 \%$ dari jumlah siswa dalam kelas telah mendapatkan nilai mencapai KKM kimia kelas X-MIPA-1 sebesar 75.

\section{Hasil Penelitian dan Pembahasan}

Penelitian ini dilakukan dalam dua siklus, setiap siklusnya berlangsung dua kali pertemuan atau pembelajaran tatap muka (setiap pertemuan $=2 \times 45$ menit). Tiap siklus

$$
\begin{aligned}
& \bar{X}=\frac{\text { jumlah.hasil. pengamatan }}{\text { jumlah } \text { pengamat }}=\frac{P_{1}+P_{2}}{2} \\
& \text { Dimana: } \quad \% \quad=\text { Persentase pengamatan } \\
& \bar{X} \quad=\text { Rata-rata } \\
& \sum \bar{X}=\text { Jumlah rata-rata } \\
& P_{1} \quad=\text { Pengamat } 1 \\
& \mathrm{P}_{2} \quad=\text { Pengamat } 2
\end{aligned}
$$

penelitian terdiri dari empat tahapan kegiatan utama, yaitu perencanaan, tindakan, pengamatan dan refleksi. Hasil data yang dikumpulkan dalam tiap siklus adalah data yang berhubungan dengan hasil belajar dan aktivitas belajar siswa dengan instrumenpengumpul data yang telah ditetapkan, yaitu melalui lembar soal tes dan format observasi yang telah disiapkan oleh peneliti.

Setelah kegiatan Siklus I danSiklus II, diperoleh data-data hasil belajar dan data-data aktivitas belajar, maka data tersebut dapat disajikan dalam bentuk Tabel. Pengambilan data diperoleh dalam empat kali pertemuan (4RPP) yang terbagi menjadi dua Siklus. Pertemuan pertama dan pertemuan kedua masuk Siklus I, dan pertemuanketiga dan pertemuan keempat masuk Siklus II. Sebelum kegiatan belajar mengajar dilakukan tes hasil belajar atau disebut pre-tes. Análisis data menunjukan hasil pre-tes siswa diperoleh rata-rata adalah 45, hal ini menunjukan siswa belum ada persiapan sebelum belajar di sekolah.

\section{Data Siklus 1}

\section{Tahap Perencanaan}

Pada tahap ini peneliti mempersiapkan perangkat pembelajaran yang terdiri dari RPP-1 dan RPP-2, LKS-1 dan LKS-2, serta mengerjakan soal tes formatif-1, dan alat-alat pengajaran dan media untuk mendukung kegiatan belajar mengajar. 


\section{Tahap Pelaksanaan}

Pelaksanaan kegiatan belajarmengajar untuk siklus I dilaksanakan pada hari Selasa tanggal 05 Agustus 2019 dan Sabtu tanggal 10 Agustus 2019 di kelas X-MIPA-1 dengan jumlah siswa 31 siswa. Dalam hal ini peneliti bertindak sebagai guru. Adapun proses belajar mengajar mengacu pada rencana pelajaran yang telah dipersiapkan.Pengamatan(observasi) dilaksanakan bersamaandengan pelaksanaan belajar mengajar.

\section{Tahap Observasi}

Akhir Siklus I dilakukan tes hasil belajar atau disebut Formatif I, dengan data dapat dilihat Pada Tabel I. Merujuk pada kesimpulan ini guru sebagai peneliti berusaha memperbaiki proses dan hasil belajar siswa Melalui Model Pembelajaran Discovery Learning. Hasil belajar yang diperoleh pada Siklus I selama dua pertemuan disajikan dalam tabel I berikut:

Tabel I : Distribusi Hasil Formatif I

\begin{tabular}{|c|c|c|c|c|}
\hline NO & NILAI & FREKUENSI & $\begin{array}{c}\text { KETUNTASAN } \\
(\%)\end{array}$ & \multirow{2}{*}{ RATA-RATA } \\
\hline 1 & 85 & 7 & 23 & \multirow{2}{*}{69} \\
\hline 2 & 75 & 11 & 35 & \\
\hline 4 & 60 & 7 & & \\
\hline & 49 & 6 & 58 & \\
\hline
\end{tabular}

Pada Tabel tersebut, nilaiterendah Formatif I adalah 49 sebanyak 6 orang dan nilai tertinggi adalah 85 sebanyak 7 orang, dengan 13 orang mendapat nilai dibawah kriteria ketuntasan atau ketuntasan klasikal adalah sebesar 58\%. Dengan nilai KKM sebesar 75. Nilai ini berada di bawah kriteria keberhasilan klasikal sehingga dapat dikatakan pembelajaran Siklus I belum maksimal memberi ketuntasan belajar dalam kelas. Nilai ratarata kelas siswa juga belum tuntas sebesar 75 .

\section{Data Aktivitas Pada Siklus I}

Setelah guru selesai menyajikan materi pembelajaran, maka siswadisuruh bekerja berkelompok untukmengerjakan LKS. Siswa bekerja dalam kelompok, peneliti memberikan instrument aktivitas siswa kepada pengamat. Untuk merekam aktivitas siswa dilakukanoleh dua pengamat sesuai dengan instruksi oleh peneliti. Kedua pengamat melakukan pengamatan selama empat kali atau Siklus I dan Siklus II. Data aktivitas siswa hasil analisis yang dilakukan oleh kedua pengamat diserahkan kembali kepada peneliti. Hasil analisis aktivitas siswa dari kedua pengamat selama empat kali dapat dilihat pada tabel II.

Tabel 2. Skor aktivitas belajarsiswa Pada Siklus I

\begin{tabular}{|c|l|c|}
\hline NO. & \multicolumn{1}{|c|}{ AKTIVITAS SISWA } & PERSENTASE (\%) \\
\hline 1 & Menulis dan membaca & 50 \\
\hline 2 & Mengerjakan & 20 \\
\hline 3 & Bertanya pada teman & 15 \\
\hline 4 & Bertanya pada guru & 5 \\
\hline 5 & Yang tidak relevan & 10 \\
\hline \multicolumn{2}{|c}{ JUMLAH } & 100 \\
\hline
\end{tabular}

\section{Refleksi}

Berdasarkan data tabel II diperoleh bahwa rata-rata formatif 69 pada Siklus I dengan persentase adalah 58\%. Hasil tersebut menunjukkan bahwa pada Siklus I secara klasikal 
siswa belum tuntas penguasaan konsepnya, karena siswa yang memperoleh nilai $\geq 75$ hanya sebesar 58\% lebih kecil dari persentase ketuntasan yang dikehendaki yaitu sebesar $85 \%$. Hal ini disebabkan karena siswa masih belum aktif terlibat dalam proses pembelajaran. Ketika siswamempresentasikan hasil diskusinya, ada beberapa kelompok yang masih diam.

Belum tercapainya standar ketuntasan tersebut tidak terlepas dari rendahnya aktivitas belajar siswa. Berdasarkan pada Tabel II, pada Siklus I rata-rata aktivitas I yakni menulis dan membaca memperoleh proporsi 50\%. Aktivitas mengerjakan dalam diskusi mencapai $20 \%$. Aktivitas bertanya pada teman sebesar 15\%. Aktivitas bertanya kepada guru $5 \%$ dan aktivitas yang tidak relevan dengan KBM sebesar 10\%. Aktivitas membaca memperoleh proporsi lebih besar dibandingkan aktivitas mengerjakan. Hal ini berarti siswa belum mempersiapkan diri dari rumah, sehingga pada saat diskusi siswa masih banyak yang membaca dibandingkan mengerjakan LKS. Pada proses pembelajaran masih ditemukan halhal yang perlu mendapatkan perhatian berkaitan dengan penelitian tindakan kelas yaitu :

1) Guru maksimal dalam memotivasi siswa dan dalam menyampaikan tujuan pembelajaran.

2) Saat melakukan kegiatan praktik, sebagian siswa aktif melakukan kegiatan dan sebagian lagi ada yang kurang aktif. Artinya masih ada siswayang tidak berpartisipasi dalam kelompoknya. Hal ini didukung dengan data aktivitas yang tidak relavan dengan PBM sebesar $10 \%$.

3) Guru belum maksimal dalam pengelolaan waktu. Kemungkinan besar penyebabnya waktu yang terlalu singkat untuk melakukan praktikum dan penyelesaian LKS, sehingga terkesan terburu-buru.

4) Respon siswa, saat gurubertanya, beberapa siswa aktif menjawab dan beberapa siswa ada yang diam. Siswa kurang begitu antusias selama pembelajaranberlangsung siswa tersebut hanyaberdiam diri, seolah-olah tidak mau tahu dan hanya melakukan kegiatan menulis dan membaca, meskipun adabeberapa siswa yang aktif dalam berargumen.

5) Siswa belum rapi dalam menuliskan hasil diskusi serta gagasannya di papan tulis.

Dari paparan hasil penelitian tindakan kelas siklus I, maka di dalam refleksi diupayakan perbaikan untuk meningkatkan proses pembelajaran dan aktivitas belajar siswa pada Siklus II, beberapa perbaikan pembelajaran dilakukan antara lain:

Guru perlu lebih terampil dalam memotivasi siswa dan lebih jelas dalam menyampaikan tujuan pembelajaran. Dimana siswa diajak untuk terlibat langsung dalam setiap kegiatan yang akan dilakukan.

a) Guru memperhatikan siswa yang tidak terlibat aktif dalam praktikum, siswa yang main-mainlebih diberi perhatian.

b) Guru perlu mendistribusikan waktu secara baik dengan menambahkan informasiinformasiyang dirasa perlu dan memberi catatan

c) Guru harus lebih terampil dan bersemangat dalam memotivasi siswa sehingga siswa bisa lebih antusias.

d) Melakukan patokan pada format analisis yang mengarahkan pada kesimpulan sehingga siswa dapat melakukan pengambilan kesimpulan secara runtun dan sistematis

\section{Data Siklus 2}

\section{Tahap Perencanaan}

Sebelum peneliti melakukan penelitian lanjutan siklus II dilaksanakan, peneliti melakukan refleksi tanggal 19 Agustus 2019 dilakukan refleksi. Refleksi bertujuan untuk: 
1) Memecahkan masalah dan kendala-kendala pada siklus I,

2) Membuat rancangan tindakandi siklus II,

3) Melakukan evaluasi terpadu terhadap peningkatan hasil belajar ranah kognitif dan afektif. Pertemuan ini menghasilkan langkah-langkah sebagai berikut adalah:

a) Melakukan persiapan dan menyusun pembuatan rancangan pengajaran yang lebih komprehensif pada siklus II.

b) Penelitian tindakan kelas siklus II tetap membutuhkan kerjasama rumpun mengingat penelitian ini tidak dapat berjalan dengan baik tanpa adanya dukungan dan kerjasama dari anggota rumpun.

c) Persiapan media dan sumber belajar juga dilakukan di siklus II misalnya buku paket, visualisasi gambar dan lain- lain. Pada siklus II penelitian tindakan kelas tetap memakai observer (pengamat), maka dibuat juga format observasi untuk memudahkan pengamat melakukan penilaian dan refleksi.

d. Pada tahap ini peneliti mempersiapkan perangkat pembelajaran yang terdiri dari rencana pelajaran 3 dan 4, LKS 3 dan 4, soal tes formatif II, dan alat-alat pembelajaran dan media untuk mendukung kegiatan belajar mengajar.

\section{Tahap Kegiatan dan Pengamatan}

Pelaksanaan kegiatan belajar mengajar untuk siklus II dilaksanakan pertemuan ke-3 pada Rabu tanggal 21 Agustus 2019 dan pertemuan ke-4 hari Sabtu tanggal 24Agustus 2019 di kelas X-MIPA-1 dengan jumlah siswa 31 siswa. Dalam hal ini peneliti bertindak sebagai guru. Adapun proses belajar mengajar mengacu pada rencana pelajaran dengan memperhatikan revisi pada siklus I, sehingga kesalahan atau kekurangan pada siklus I tidak terulang lagi pada siklus Pengamatan (observasi) dilaksanakan bersamaan dengan pelaksanaan belajar mengajar.

\section{Tahap Observasi}

Pada akhir proses belajar mengajar siswa diberi tes formatif II dengan tujuan untuk mengetahui tingkat keberhasilan siswa dalam proses belajar mengajar yang telah dilakukan.Instrument yangdigunakan adalah tes formatif II. Adapun data hasil penelitian pada siklus II datanya dapat dilihat pada tabel III adalah sebagai berikut:

Tabel 3. Distribusi Hasil Formatif II

\begin{tabular}{|c|c|c|c|c|}
\hline NO & NILAI & FREKUENSI & $\begin{array}{c}\text { KETUNTASAN } \\
(\%)\end{array}$ & \multirow{2}{*}{ RATA-RATA } \\
\hline 1 & 100 & 9 & 29 & \multirow{2}{*}{8} \\
\hline 2 & 85 & 19 & 61 & \\
\hline 3 & 70 & 2 & - & \\
\hline 4 & 60 & 1 & 90 & \\
\hline
\end{tabular}

Berdasarkan hasil pada tabel III, nilai terendah untuk Formatif II adalah 60 sebanyak 1 orang dan tertinggi adalah 100 sebanyak 9 orang. Dengan 3 orang mendapat nilai dibawah kriteria ketuntasan atau ketuntasan klasikal adalah sebesar 90\%. Nilai ini berada di atas kriteria keberhasilan sehingga dapat dikatakan KBM Siklus II berhasil memberi ketuntasan belajar dalam kelas. Nilai rata-rata kelas adalah 88 .

Berdasarkan analisis data, diperoleh aktivitas siswa dalam proses pembelajaran kimia pada materi pelajaran larutan elektrolit dan non elektrolit yang paling dominan adalah aktivitas mengerjakan, bertanya kepada guru, dan diskusi antar siswa/antara siswa dengan guru. Jadi dapat dikatakan bahwa aktivitas siswa dapat dikategorikan aktif. 
Penskoran dilakukan dan dijabarkan dalam data berupa tabel aktivitas oleh pengamat I dan II untuk Siklus II sebagai berikut:

Tabel 4. Skor aktivitas belajarsiswa Pada Siklus II

\begin{tabular}{|c|l|c|}
\hline NO. & \multicolumn{1}{|c|}{ AKTIVITAS SISWA } & PERSENTASE (\%) \\
\hline 1 & Menulis dan membaca & 21 \\
\hline 2 & Mengerjakan & 50 \\
\hline 3 & Bertanya pada teman & 13 \\
\hline 4 & Bertanya pada guru & 16 \\
\hline 5 & Yang tidak relevan & 1 \\
\hline \multicolumn{2}{|c|}{ JUMLAH } & 100 \\
\hline
\end{tabular}

\section{Refleksi}

Hasil belajar siswa diakhir Siklus II telah mencapai ketuntasan klasikal 90\%, yang berarti hampir seluruh siswa telah memperoleh nilaituntas dengan tiga orang siswa yang belum mendapatkan nilai di atas KKM. Dengan demikian tindakan yang diberikan pada Siklus II telah berhasil memberikan perbaikan hasil belajar pada siswa. Pada tahap ini akan dikaji apa yang telah terlaksana dengan baik maupun yang masih kurang baik dalam proses belajar mengajar dengan penerapan model pembelajaran Discovery Learning. Dari data-data yang telah diperoleh dapat duraikan sebagai berikut:

a) Selama proses belajar mengajar guru telah melaksanakan semua pembelajaran dengan baik. Meskipun ada beberapa aspek yang belum sempurna, tetapi persentase pelaksanaannya untuk masing-masing aspek cukup besar.

b) Berdasarkan data hasil pengamatan, diketahui bahwa siswa aktif selama proses belajarberlangsung. Ini dikarenakan siswa sudah mulai terbiasa dengan bekerjasecara kelompok.

c) Siswa mulai aktif dan tahu akan tugasnya sehingga tidak menggantungkan permasalahanyang dihadapi kepada teman dalam kelompoknya.

d) Respon siswa, saat gurumemberikan arahan dan siswamelakukan kegiatan dengan aktif.

e) Hasil belajar siswa pada siklusII mencapai ketuntasan.

Pada Siklus II, pelaksanaan pembelajaran Discovery Learning berbantuan LKS, tindakan berupa menampilkan alat peraga dan pemberian penugasan yang memunculkan banyak aktivitas sudah efektif. Pada siklus II guru telah menerapkan model pembelajaran Discovery Learning dengan baik dan dilihat dari aktivitas siswa serta hasil belajarsiswa pelaksanaan proses belajar mengajar sudah berjalan dengan baik. Maka tidak diperlukan revisi terlalu banyak, tetapi yang perlu diperhatikan untuk tindakan selanjutnya adalah memaksimalkan dan mempertahankan apa yang telah ada dengan tujuan agar pada pelaksanaan proses belajar mengajar selanjutnya penerapan pembelajaran Discovery Learning dapat meningkatkan proses belajar mengajar sehingga tujuan pembelajaran dapat tercapai dengan maksimal.

Dari data hasil penelitian diketahui bahwa aktivitas belajar siswa dalam segala aspek pengamatan mengalami peningkatan yang sangat berarti dari siklus I ke siklus II. Penerapan model pembelajaran Discovery Learning yang menekankan pada pemahaman konsep kepada siswa, guru mengawali pengajaran dengan menyajikan data atau contoh dan yang bukan contoh, kemudian guru meminta siswa untuk mengamati data atau contoh tersebut, dan siswa dibimbing agar mampu mengidentifikasi ciri-ciri/karakteristik dari contoh yang diberikan. Hasil penelitian menunjukkan ada peningkatan hasil belajar siswa 
dan penguasaan konsep siswa melalui model pembelajaran Discovery Learning pada materi larutan elektrolit dan non elektrolit kelas X-MIPA-1 SMA Negeri 1 Praya Barat tahun pelajaran 2019/2020. Hal ini di dapat dilihat dari rata-rata hasil pretes siswa sebelum diterapkan model pembelajaran Discovery Learning yaitu 45 meningkat pada siklus I menjadi 69 dan Siklus II menjadi 88 yaitu dengan ketuntasan klasikal masing-masing 58\% dan 90\%. Pembelajaran Discovery Learningmerupakan salah satu model pembelajaran dengan pendekatan saintifik. Model pembelajaran Discovery Learning mendorong siswa lebih aktif dalam belajar sehingga siswa akan mendapatkan pemahaman yang lebih baik mengenai materi dan akan lebih tertarik terhadap materi yang disampaikan. Keterlibatan aktif siswaterbukti dapat meningkatkan prestasi belajar dan sikap siswa terhadap materi pelajaran. Adapun hasil penelitian ini sejalan dengan penelitian Istiana et al (2015) \& Kurnianto et al (2016) yang menjelaskan bahwa model pembelajaran Discovery Learning dapat meningkatkan aktifitas dan prestasi belajar siswa.

\section{Kesimpulan}

Kesimpulan yang diperoleh dari hasil penelitian ini adalah; (1) Aktivitas belajar kimia siswa meningkat dengan menerapkan model pembelajaran Discovery Learning pada materi larutan elektrolit dan non elektrolit menurut kedua pengamatan pada Siklus I aktivitas menulis da membaca $50 \%$, mengerjakan LKS 20\%, bertanya sesama teman $15 \%$, bertanya kepada guru 5\%, dan yang tidak relevan dengan kegiatan belajar mengajar 10\% sedangkan menurut pengamatan Siklus II aktivitas menulis dan membaca $21 \%$, mengerjakan LKS $50 \%$, bertanya sesama teman 13\%, bertanya kepada guru 16\%, dan yang tidak relevan dengan kegiatan belajar mengajar 1\%. (2) Hasil belajar kimia siswa meningkat dengan menerapkan model pembelajaran Discovery Learning pada materi larutan elektrolit dan non elektrolit pada Formatif I menunjukkan 18 orang siswa tuntas secara individu, sedangkan pada Siklus II, 28 orang siswa tuntas secara individu dan kelas tuntas dengan rata-rata siklus I dan siklus II adalah 69 dan 88 , persentase ketuntasan klasikal adalah 58\% pada siklus I dan $90 \%$ pada siklus II.

\section{Saran}

Dari hasil yang diperoleh dalam penelitian ini, maka ada beberapa saran yang diajukan yaitu:

1) Pada saat proses pembelajaran berlangsung peneliti mengalami kendala yaitu keadaan siswa yang kurang termotivasi untuk berpartisipasi aktif dalam pembelajaran. Maka untuk kasus seperti ini disarankan agar melakukan pengelolaan kelasdengan baik.

2) Pada saat diskusi kelompok berlangsung peneliti masihkesulitan dalam membimbing penuh pada masing-masing kelompok. Oleh sebab itu, bagi peneliti selanjutnya disarankan agar lebih membimbing siswa dengan cara aktif bertanya kepada siswa tentang kendala yang dihadapi, memotivasi, dan mengarahkan agar setiap siswa aktif berdiskusi dengan menjelaskan nilai dari satu orang siswa dapat mempengaruhi nilai dan nama baik kelompok serta memberikan penghargaan berupa nilai plus kepada siswa yang aktif agar siswa lebih termotivasi dan dapat berdiskusi dengan baik.

3) Pada saat proses pembelajaran berlangsung peneliti mengalami kendala dalam pembagian waktu. Sehingga bagi peneliti selanjutnya yang ingin menerapkan model pembelajaran Discovery Learning ini disarankan agar lebih memperhatikan penggunaan waktu didalam pembelajaran untuk setiap fasenya karena pada model pembelajaran ini memerlukan waktu yang banyak khususnya ketika siswa melakukan 
diskusi dan mempresentasikan hasildiskusi.

\section{Daftar Pustaka}

Aqib, Z. (2006). Penelitian TindakanKelas. Bandung: Yrama Widya

Anisa, N., Septiana, I., \& Purbiyanti, E. (2021). Penerapan Model Pembelajaran Discovery Learning Berbantuan Media Interaktif untuk Meningkatkan Hasil Belajar Peserta Didik di SDN 1 Kebonadem Kabupaten Kendal. Jurnal Paedagogy, 8(3), 460-466. doi:https://doi.org/10.33394/jp.v8i3.3912

Aunurrahman. (2009). Belajar dan Pembelajaran. Bandung :Alfabeta

Deviana, M., Subekti, E., \& Kuswandari, K. (2021). Peningkatan Hasil Belajar IPA pada Pembelajaran Tema 9 Melalui Model Discovery Learning Berbantuan Media Powerpoint bagi Siswa Kelas V SDN 2 Tanggung. Jurnal Paedagogy, 8(3), 345-350. doi:https://doi.org/10.33394/jp.v8i3.3891

Fitriana, F. (2019). Penerapan Model Discovery Learning pada Pembelajaran IPA Materi Tekanan untuk Meningkatkan Hasil Belajar Siswa. Jurnal Kependidikan: Jurnal Hasil Penelitian dan Kajian Kepustakaan di Bidang Pendidikan, Pengajaran dan Pembelajaran, 5(2), 100-108. doi:https://doi.org/10.33394/jk.v5i2.1805

Istiana, G.A., Catur, A.N.S., dan Sukardjo, J.S. (2015). Penerapan Model Pembelajaran Discovery Learning untuk Meningkatkan Aktivitas dan Prestasi Belajar Pokok Bahasan Larutan Penyangga Pada Siswa Kelas XI IPA Semester II SMA Negeri 1 Ngemplak Tahun Pelajaran 2013/2014. Jurnal Pendidikan Kimia, 4(2): 65-73

Jakarta: Raja Grafindo Persada. Slameto. (2003). Belajar dan Faktor- Faktor yang Mempengaruhinya. Jakarta:Rineka Cipta.

Kurnianto, H., Masykuri, M., dan Yamtinah, S. (2016). Pengaruh Model Pembelajaran Discovery Learning Disertai Lembar Kegiatan Siswa (LKS) Terhadap Prestasi Belajar Siswa Pada Materi Hidrolisis Garam Kelas XI SMA Negeri 1 Karanganyar Tahun Pelajaran 2014/2015. Jurnal Pendidikan Kimia, 5(1): 32-40.

Luthfi, M., Huda, C., \& Susanto, J. (2021). Penerapan Model Pembelajaran Discovery Learning Untuk Meningkatkan Keaktifan Belajar Siswa pada Pembelajaran Tematik Kelas V Tema 8 di SD Negeri 1 Selo Kabupaten Grobogan Jawa Tengah. Jurnal Paedagogy, 8(3), 422-430. doi:https://doi.org/10.33394/jp.v8i3.3902

Mahartati, I. (2017). Meningkatkan Motivasi dan Hasil Belajar Tematik Peserta Didik dengan Mengoptimalkan Penerapan Model Discovery Learning di SD Negeri 3 Cakranegara. Jurnal Kependidikan: Jurnal Hasil Penelitian dan Kajian Kepustakaan di Bidang Pendidikan, Pengajaran dan Pembelajaran, 3(2). doi:https://doi.org/10.33394/jk.v3i2.568

Nurmiati, B. (2020). Meningkatkan Motivasi dan Hasil Belajar Peserta Didik dengan Mengoptimalkan Penerapan Model Discovery Learning di SD Negeri 2 Cakranegara. Jurnal Paedagogy, 6(1), 1-7. doi:https://doi.org/10.33394/jp.v6i1.2523

Raihun, R. (2019). Penerapan Model Pembelajaran Discovery Learning untuk Meningkatkan Prestasi Belajar PPKn Peserta Didik Kelas IX.3 SMP Negeri 4 Praya Timur. Jurnal Kependidikan: Jurnal Hasil Penelitian dan Kajian Kepustakaan di Bidang Pendidikan, Pengajaran dan Pembelajaran, 5(2), 124-132. doi:https://doi.org/10.33394/jk.v5i2.1809

Saufi, I., \& Rizka, M. (2021). Analisis Pengaruh Media Pembelajaran Film Dokumenter Terhadap Motivasi Belajar Siswa. Jurnal Teknologi Pendidikan : Jurnal Penelitian dan Pengembangan Pembelajaran, 6(1), 55-59. 
doi:https://doi.org/10.33394/jtp.v6i1.3626

Setiarini, A. (2016). Meningkatkan Motivasi dan Hasil Belajar Peserta Didik dengan Mengoptimalkan Penerapan Pendekatan Saintifik Strategi Discovery Learning dan Metode Diskusi di SDN Model Mataram. Jurnal Kependidikan: Jurnal Hasil Penelitian dan Kajian Kepustakaan di Bidang Pendidikan, Pengajaran dan Pembelajaran, 2(1). doi:https://doi.org/10.33394/jk.v2i1.390

Suarni, G., Rizka, M., \& Zinnurain, Z. (2021). Analisis Pengaruh Penerapan Model Pembelajaran Sains Teknologi Masyarakat Terhadap Hasil Belajar Siswa. Jurnal Paedagogy, 8(1), 31-38. doi:https://doi.org/10.33394/jp.v8i1.3226

Trianto. (2007). Model-Model Pembelajaran Inovatif Prosedur Penelitian Suatu Pendekatan Praktik. Jakarta: Rineka Cipta. 